\title{
POLA LETAK STRUKTUR PONDASI PADA RUMAH LAMA PEKANBARU
}

\author{
Oleh : \\ Boby Samra \\ boby@unilak.ac.id
}

Program Studi Arsitektur Fakultas Teknik Unilak Jalan Yos Sudarso km 8 Pekanbaru

\begin{abstract}
Abstrak
Bangunan rumah lama kota pekanbaru merupakan bagian dari perkembangan kota dari masa lampau kemasa sekarang, perkembangan penduduk pada saat ini menjadikan rumah tersebut tumbuh dengan kebutuhan dan tidak menghiraukan karakter dari rumah lama. Maka dari itu perlu dilakukan penelitian seperti apa sebenarnya pola letak dari struktur pondasi bangunan lama ini dengan kondisi lingkungan yang ada.Tulisan ini disusun melalui penelitian dengan pendekatan kualitatif, serta serangkaian pengumpulan dan pengelolaan data lapangan yang didapat melalui metode operasional seperti observasi, wawancara, dokumentasi dan diskusi. Melalui tulisan ini, diharapkan dapat memberikan pemahaman dari pola struktur pondasi rumah lama pekanbaru.
\end{abstract}

Kata Kunci: Pola, pondasi, Rumah

\section{Pendahuluan}

Perkembangan sejumlah permukiman di wilayah tepi sungai siak adalah merupakan daerah yang paling strategis untuk bermukim. Khususnya bagi kaum pendatang yang pada awalnya menggunakan transportasi air, maka daerah pinggiran sungai adalah yang paling mudah dicapai, yang kemudian digunakan sebagai tempat tinggal, tempat berusaha, baik untuk sementara maupun menetap. Lebih dari itu air adalah sumber kehidupan, sehingga manusia tidak bisa hidup jauh dari air.

Pertumbuhan penduduk juga dibarengi dengan pertumbuhan bangunan pada kawasan tersebut, sehingga bentuk dari bangunan juga mengalami perubahan yang siknifikan. Hakikatnya rumah memiliki fungsi ganda, yakni sebagai tempat diam, tempat berkumpul keluarga, kaum kerabat dan handai tolan, tempat berteduh sanak saudara, tempat beranak berketurunan, selain itu rumah juga berfungsi sebagai tempat beradat berlembaga, sebagai simbol tanggung jawab seseorang terhadap keluarganya, symbol tuah dan marwah, simbol harkat dan martabat (Tenas Efendi, 2003). 
Bentuk rumah dan struktur pondasi bangunan rumah lama pada kawasan Senapelan perlu mendapat perhatian karna kawasan tersebut merupakan bentuk peninggalan dan kejayaan masalalu dari perkembangan kota Pekanbaru. Setiap rumah lama selalu memiliki bentuk, karakter, kaidah-kaidah yang berbeda dari setiap daerah yang berhubungan juga dengan kondisi lingkungan fisik daerah tersebut. Pencarian pola struktur pondasi pada bangunan rumah lama Senapelan dilakukan untuk mengetahui makrokosmos lingkungan alam pada kawasan tersebut.

\section{Metode Penelitian}

Lokasi Penelitian dititik beratkan pada Kampung Bandar dan Kampung Bukit yang terletak di Kelurahan Kampung Bandar Kecamatan Senapelan, merupakan bagian dari perkembangan kota Pekanbaru, dahulunya kedua kampung ini merupakan bagian dari daerah Senapelan lama yang sekarang menjadi sebuah Kecamatan Senapelan di kota Pekanbaru.

Penelitian dilakukan dengan pendekatan kualitatif, dengan Analisis pertama yang dilakukan adalah melakukan survey dan pengambaran ulang secara dua dimensi, foto dengan kondisi aktual lapangan disetiap bangunan dan site dari bangunan. Pengambaran ini dilakukan sehingga nantinya dapat terlihat dengan jelas pola struktur di setiap bangunan yang menjadi studi khasus, serta elemen-elemen yang menjadi faktor pada bangunan tersebut.

Analisis kedua, dilakukan operasionalisasi pendekatan relasi terhadap teori dengan aspek struktur bentuk bangunan. Dari beberapa aspek ini bisa kita lakukan tinjau teoritis terhadap bangunan tersebut.

\section{Pembahasan Dan Hasil}

Kawasan kampung Bandar dan kampung Bukit ini merupakan kawasan yang kontur tanahnya dibagi menjadi dua bagian yaitu: pada kawasan kampung Bandar kontur tanah relative rendah yang terletak pada pinggir sungai Siak, apabila terjadi pasang yang cukup tinggi maka kawasan ini akan tergenang air, bahkan pada awalnya sebelum ada jaringan penanggulangan banjir genangan air sampai 
kekawasan pasar bawah, setelah pembangunan pintu air pada dua anak sungai Senapelan dan sungai Sago yang memberibatasan kampung ini dengan kampung lain maka kawasan ini tidak tergenang lagi. Sedangkan pada kawasan kampung Bukit kontur tanahnya cukup tinggi sehingga hal yang terjadi pada kampung Bandar tidak terjadi pada kawasan ini.
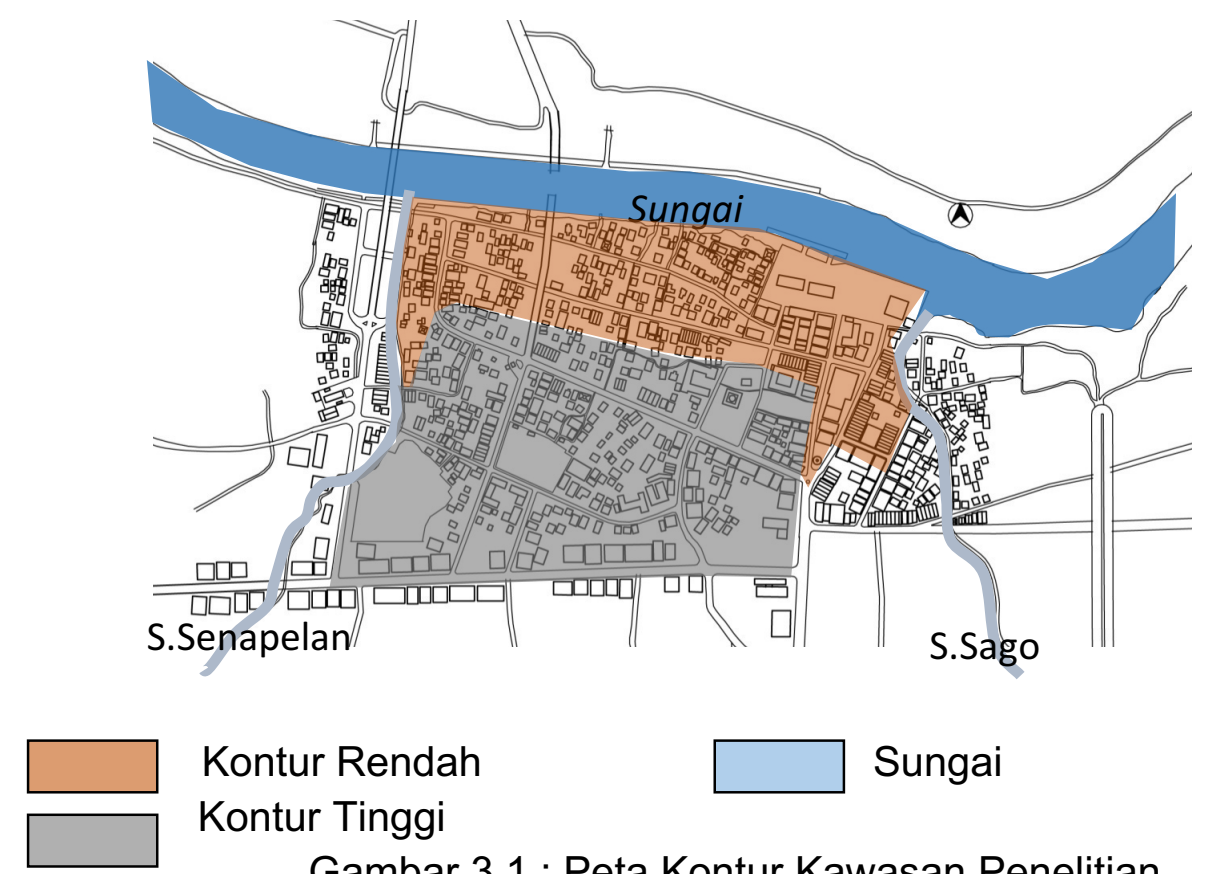

\section{Kontur Rendah \\ Kontur Tinggi}

Sungai

Gambar 3.1 : Peta Kontur Kawasan Penelitian
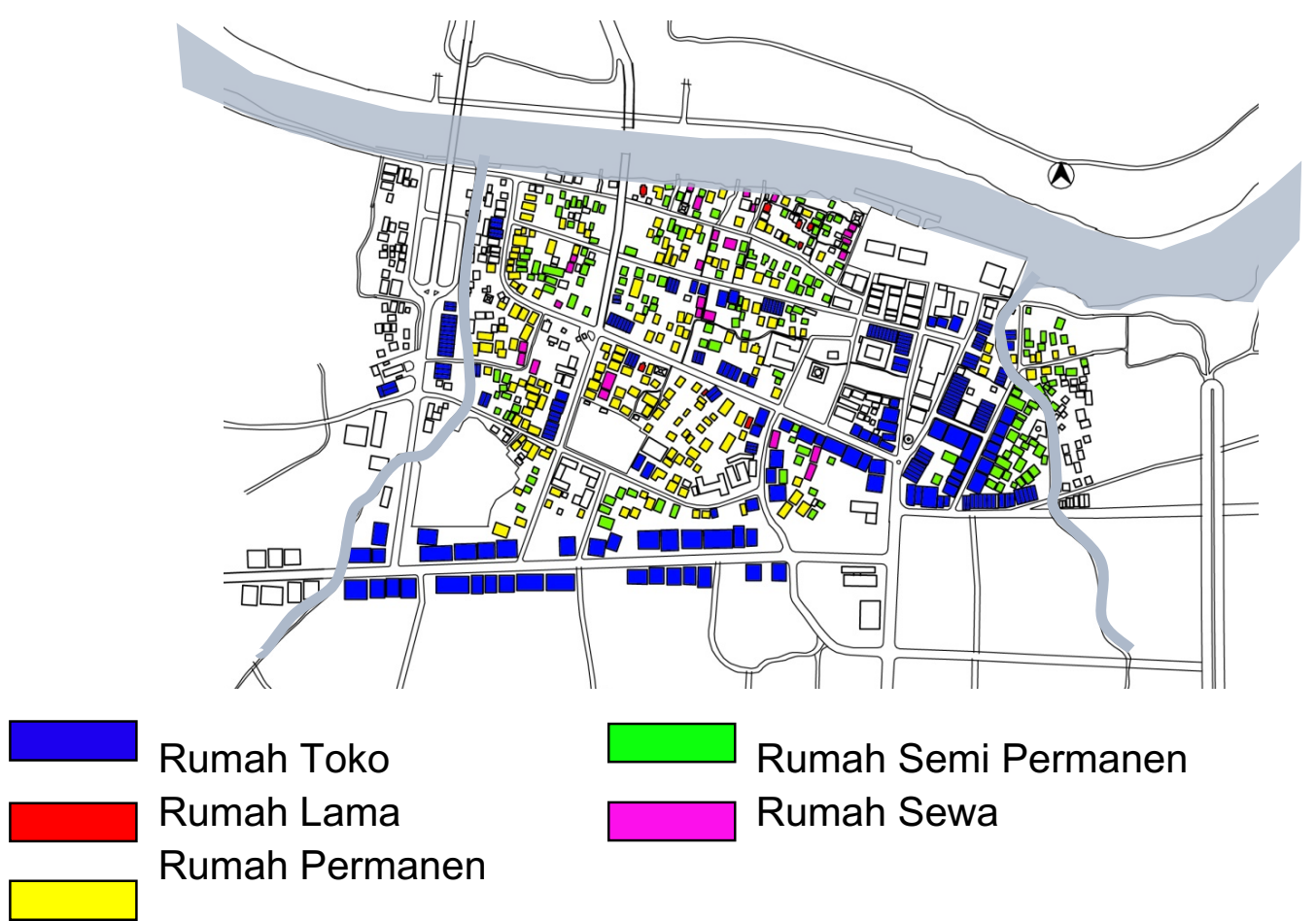

Rumah Toko

Rumah Semi Permanen

Rumah Lama

Rumah Permanen

Rumah Sewa

Gambar 3.2 : Peta Lokasi Rumah Penelitian 


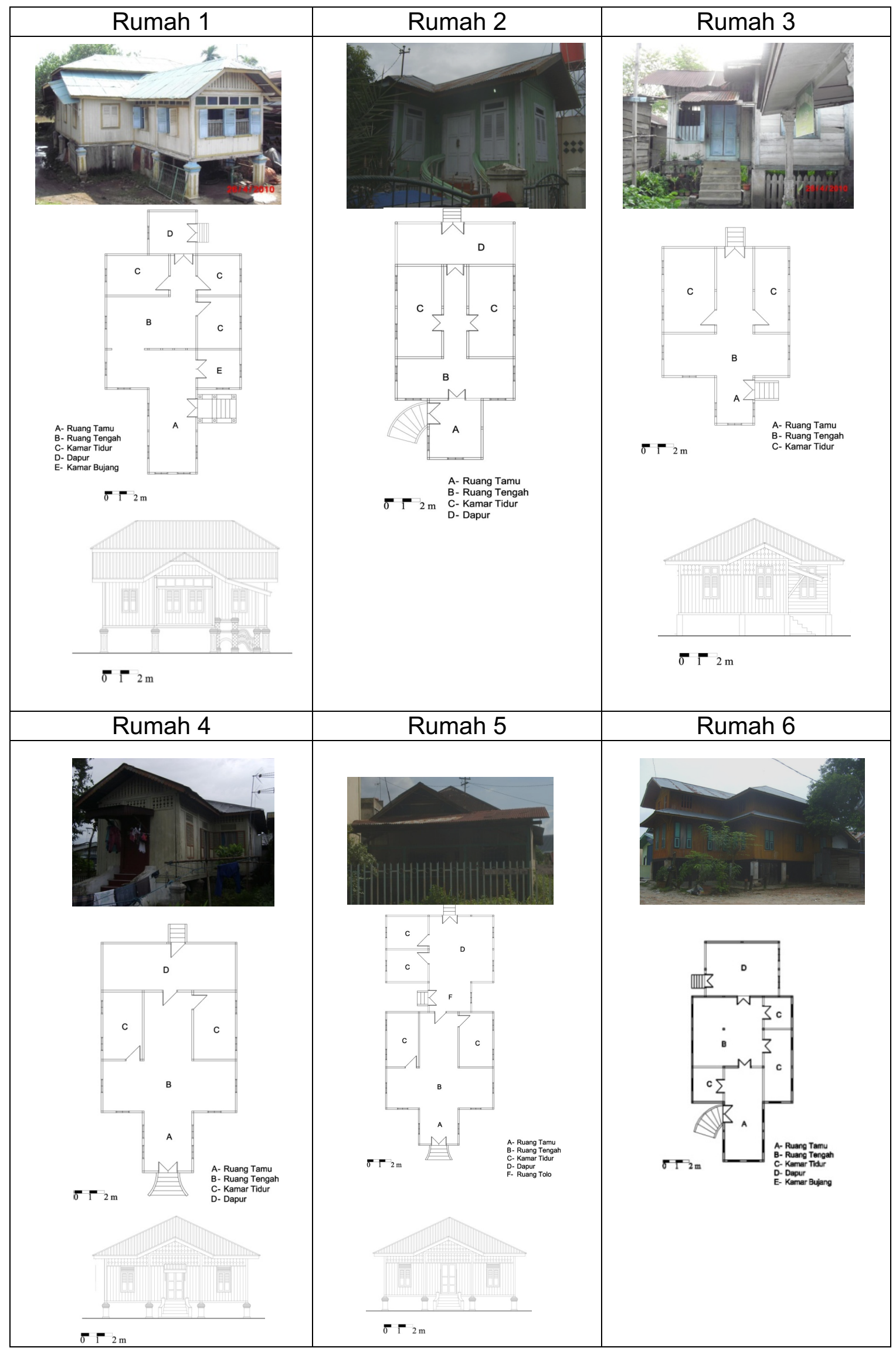

Gambar 3.3 : Denah dan Tampak Rumah Penelitian 


\section{Bentuk Struktur Pondasi}

Bangunan rumah lama pada lokasi penelitian kawasan senapelan ini terbuat dari pasangan batu bata yang mempunyai tinggi berfariasi tergantuk dimana letak bangunan tersebut, bangunan yang letaknya dekat dengan sungai cukup tinggi dikarenakan untuk menghindari dari bahaya banjir atau pengaruh air sungai yang tinggi, sedangkan untuk lokasi pada kampung Bukit rumah-rumah lama ini tidak terlalu tinggi dikarenakan ini hanya berfungsi untuk menghindari dari binatang buas. Ketinggian pondasi ini paling tinggi $180 \mathrm{~cm}$ sedangkan pondasi yang terendah adalah $120 \mathrm{~cm}$.

Bentuk dari pondasi bangunan rumah lama ini pada awalnya terbuat dari kayu keras yang biasanya dari kayu kulim, tetapi ada juga yang memang sudah dari awalnya dari pasangan batu bata, bentuk pasangan batu bata ini juga terbagi atas dua bagian yaitu bentuk polos dan berbentuk ukiran relif-relif beton.
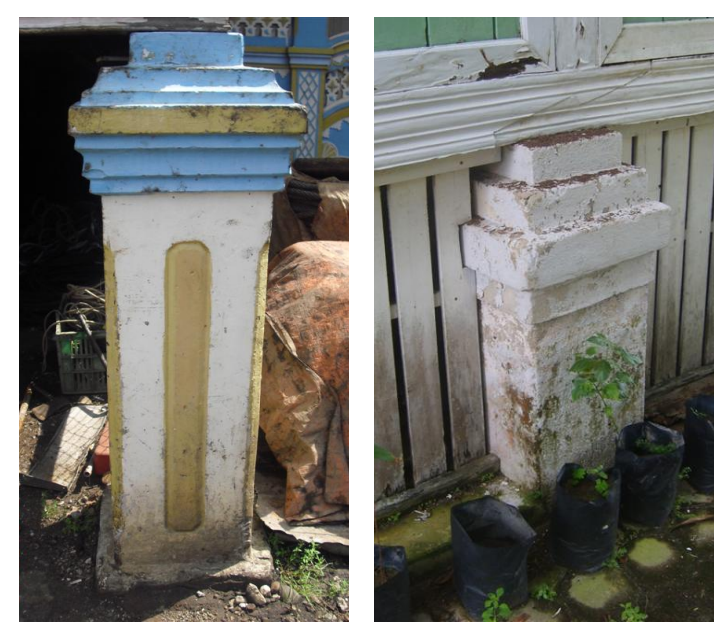

Bentuk yang di relif
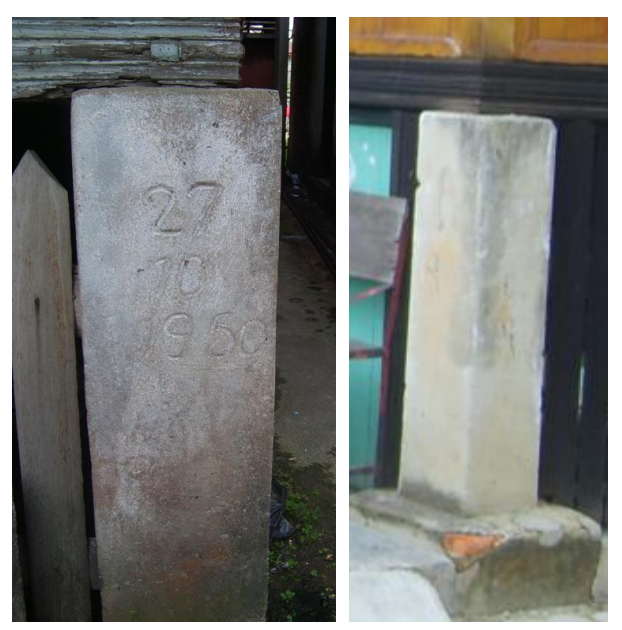

Bentuk yang pasangan bata biasa

Gambar 3.4 : Bentuk Pondasi Pasangan Batu Bata

\section{Pola Letak Struktur Pondasi}

Pola letak pondasi pada bangunan rumah lama ini menggunakan sistem grid dengan arah memanjang kearah belakang bangunan. Pondasi pada bangunan lama ini posisinya sangat menentukan terhadap tatanan atau bentuk 
ruang pada bangunan, karena posisi pondasi letak tiang bangunan untuk struktur rumah yang langsung kebalok paling atas tempat letak kuda-kuda atap. Posisi seperti ini menetukan sekali pada besaran ruang dan tatanan ruang dalam bangunan lama.

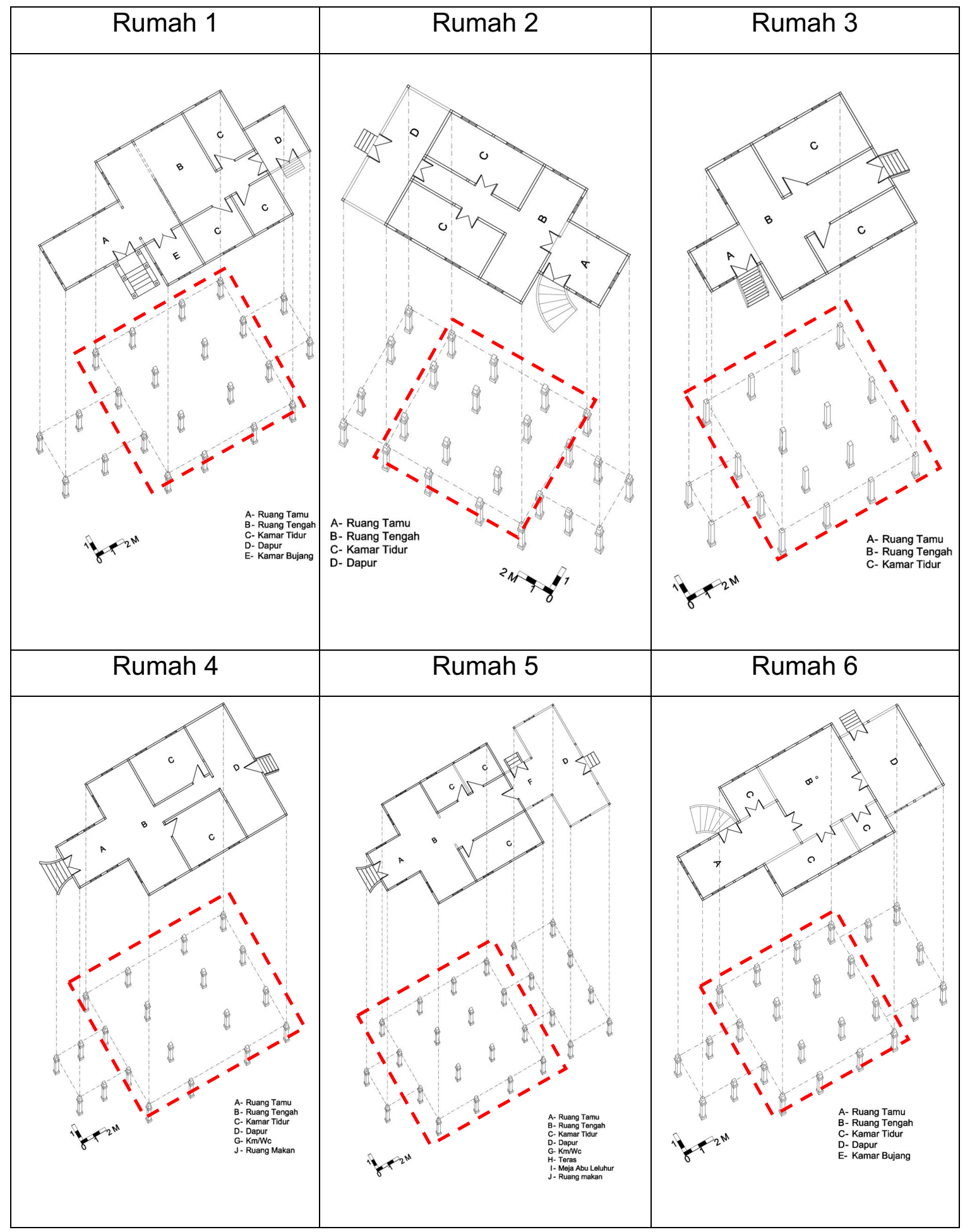

Gambar 3.5 : Pola Letak Pondasi 
Ukuran pondasi dan jarak antar pondasi tidak ada yang sama dengan rumah lain, ini dipengaruhi oleh ketersediaan kayu pada masa itu. Letak pondasi pada bangunan yang lama ini pada bangunan induk memiliki kemiripan dan mempunyai irama dan jumlah yang sama yaitu berjumlah 16 buah, sedangkan untuk bangunan teras atau ruang tamu berfariasi termasuk ruang tolo dan pedapuan.

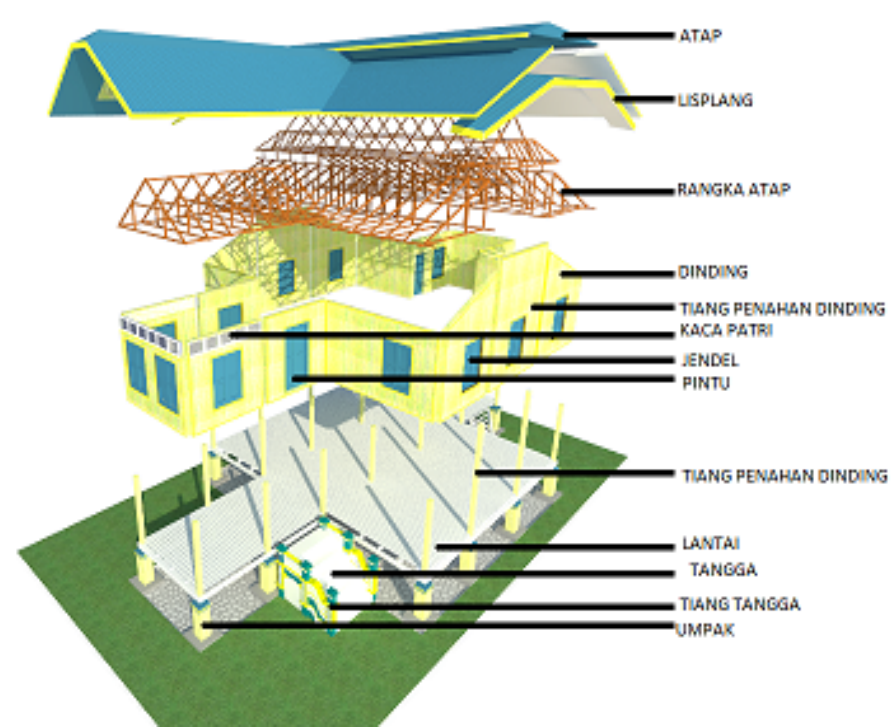

Gambar 3.6 : Susunan Struktur Bangunan Rumah

(Sumber : Tugas Mahasiswa Teknologi Bahan Kayu:2015)

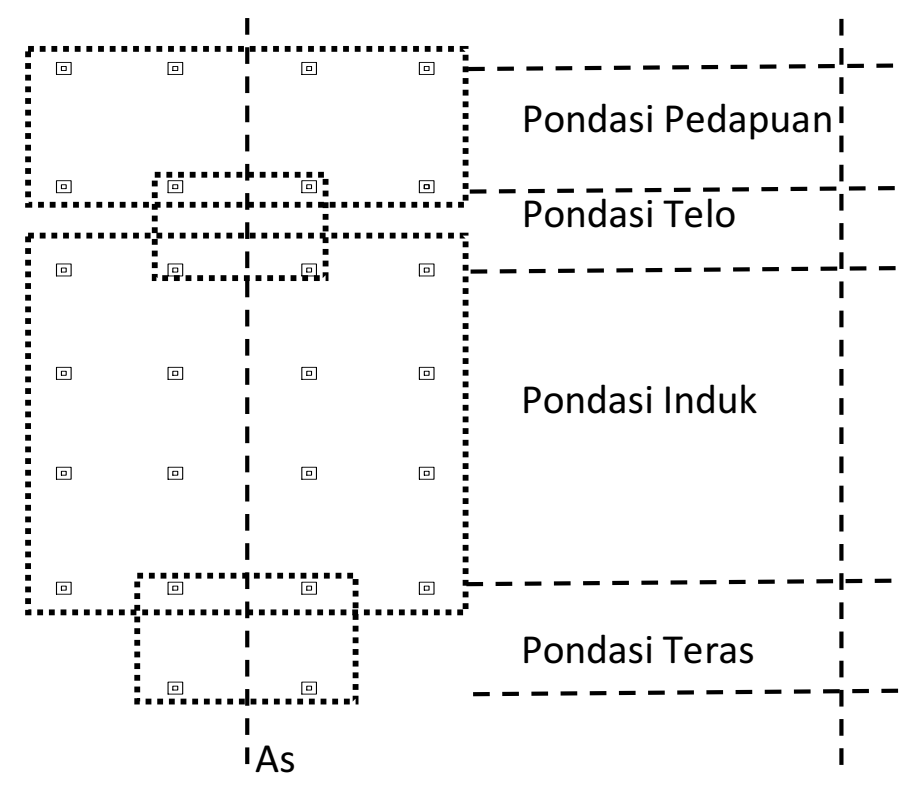

Gambar 3.6 : Susunan Simetris dari Bangunan 
Susunan yang simetris pada tiang pondasi menandakan keseimbangan dalam memahami makrokosmos lingkungan alam pada lingkungan dimana bangunan tersebut didirikan. Sedangkan empat tiang pada bangunan intuk dinamakan "tiang seri" yaitu tiang utama pada bangunan tersebut, sedangkan tiang yang terletak diantara tiang tersebut dinamakan "tiang penghulu".

\section{Kesimpulan}

Dalam analisis yang dilakukan pembentukan pola letak struktur pondasi bangunan berhubungan dengan pola ruang yang ada pada bangunan, serta pembangian dari jenis bangunan yang di terapkan pada rumah melayu. Sedangkan dari segi jumlah setiap bangunan memiliki jumlah yang sama dengan jumlah genap dengan susunan simetris. Untuk tinggi pondasi bangunan penerapan dari makrokosmos pada lingkungan sangat diperhatikan.

\section{Daftar Bacaan}

Budiharjo,Eko, 2004, Arsitektur dan kota di Indonesia, Alumni, Bandung.

Bintarto, 1983, Interaksi Desa-Kota, Ghalia Indonesia.

Cornelis van de ven, 1991, Ruang Dalam Arsitektur, Gramedia Pustaka Utama, Jakarta.

Ching Francis D.K, 2008, Arsitektur Bentuk, Ruang, dan Tatanan, Erlangga.

Departemen Pendidikan Dan Kebudayaan, 1986, Arsitektur Tradisional Daerah Riau.

Heinz Frick, 1997, Pola Struktural dan Teknik Bangunan di Indonesia, Kasinus

Heinz Frick \& Petra Widmer, 2006 Membangun, Membentuk, Menghuni, Kasinus.

Irwin Altman, Rapoport Amos and Joachim F.Wohlwill 1980, Human Behavior and Environment, Now York, N.Y, library of congress.

Jakson, John Brinckerhoff, Cetak Ulang 1984, Discovering The Vernacular Landscape, University of Louisville.

Lembaga Adat Melayu Riau,2004 Arsitektur Rumah Melayu Kota Pekanbaru.

Noeng Muhadjir, 1992. Metodologi Penelitian Kualitatif. Rake

Sarasin.Yogyakarta

Pusat penelitian Kebudayaan dan Kemasyarakatan Universitas Riau,2005 Atlas

(Ensiklopedia) Kebudayaan Melayu Riau, Pemerintah Propinsi Riau.

Poedio dan Tim, 1986, Arsitektur, Manusia, dan Pengamatannya, Djambatan

Rapoport.A, 1969, House Form and Culture,London. Prentice Hall. Inc.

Englewood Cliffs.

UU. Hamidy, 2009, Jagad Melayu Dalam Lintasan Budaya di Riau, Bilik Kreatif Press.

Wan Ghalid,1980 Sejarah Kota Pekanbaru, Pemerintah Kotamadya Tingkat II Pekanbaru. 